Article

\title{
Toxicity of Carbon, Silicon, and Metal-Based Nanoparticles to the Hemocytes of Three Marine Bivalves
}

\author{
Konstantin Pikula ${ }^{1,2, *(\mathbb{D}}$, Vladimir Chaika ${ }^{1}$, Alexander Zakharenko ${ }^{1,2}{ }^{\text {, Anastasia Savelyeva }}{ }^{3}$, \\ Irina Kirsanova ${ }^{3}$, Anna Anisimova ${ }^{3}$ and Kirill Golokhvast 1,2,4 \\ 1 Education and Scientific Center of Nanotechnology, School of Engineering, Far Eastern Federal University, \\ Sukhanova 8,690950 Vladivostok, Russia; chayka.vv@dvfu.ru (V.C.); zakharenko.am@dvfu.ru (A.Z.); \\ golokhvast.ks@dvfu.ru (K.G.) \\ 2 N.I. Vavilov All-Russian Institute of Plant Genetic Resources, B.Morskaya 42-44, \\ 190000 Saint-Petersburg, Russia \\ 3 School of Natural Sciences, Far Eastern Federal University, Sukhanova 8, 690950 Vladivostok, Russia; \\ saveleva.as@students.dvfu.ru (A.S.); kirsanova.ia@dvfu.ru (I.K.); anisimova.aale@dvfu.ru (A.A.) \\ 4 Pacific Geographical Institute, Far Eastern Branch of the Russian Academy of Sciences, Radio 7, \\ 690041 Vladivostok, Russia \\ * Correspondence: pikula_ks@dvfu.ru
}

Received: 8 April 2020; Accepted: 8 May 2020; Published: 10 May 2020

Simple Summary: The growing nanotechnology industry disposes of a variety of nanoparticles with different physiochemical properties in everyday life. However, the dependence of the safety and toxicity of nanoparticles on their physicochemical properties remains unclear. Bivalve molluscs represent an efficient model for the investigation of nanoparticle toxicity owing to their filtrating ability and feeding on particles suspended in the water. Moreover, the blood cells of bivalve molluscs, the hemocytes, have been suggested as a good analog test-object to mammalian immune cells, phagocytes. In this study, we used hemocytes of three marine bivalve species, namely, Crenomytilus grayanus, Modiolus modiolus, and Arca boucardi, to evaluate and compare the toxic effects of 10 different types of nanoparticles. We gave short-term exposure of the nanoparticles to the hemocytes and registered viability and changes in their cell membrane polarization by employing flow cytometry. Metal-based nanoparticles were the most toxic to the cells of all three tested bivalve mollusc species. However, the sensitivity to different nanoparticle types varied between species. Moreover, the registered cell membrane depolarization indicated an early toxic response and raised concern that chronic long-term exposure of nanoparticles (even if they were previously declared as safe) is a serious threat for aquatic organisms.

\begin{abstract}
Nanoparticles (NPs) have broad applications in medicine, cosmetics, optics, catalysis, environmental purification, and other areas nowadays. With increasing annual production of NPs, the risks of their harmful influence on the environment and human health are also increasing. Currently, our knowledge about the mechanisms of the interaction between NPs and living organisms is limited. The marine species and their habitat environment are under continuous stress owing to the anthropogenic activities, which result in the release of NPs in the aquatic environment. We used a bioassay model with hemocytes of three bivalve mollusc species, namely, Crenomytilus grayanus, Modiolus modiolus, and Arca boucardi, to evaluate the toxicity of 10 different types of NPs. Specifically, we compared the cytotoxic effects and cell-membrane polarization changes in the hemocytes exposed to carbon nanotubes, carbon nanofibers, silicon nanotubes, cadmium and zinc sulfides, Au-NPs, and $\mathrm{TiO}_{2} \mathrm{NPs}$. Viability and the changes in hemocyte membrane polarization were measured by the flow cytometry method. The highest aquatic toxicity was registered for metal-based NPs, which caused cytotoxicity to the hemocytes of all the studied bivalve species. Our results also highlighted different sensitivities of the used tested mollusc species to specific NPs.
\end{abstract}


Keywords: carbon nanotubes; ecotoxicology; flow cytometry; hemocytes; metal nanoparticles; bivalve mollusc; mussel; nanofibers; nanotoxicology; silicon nanotubes

\section{Introduction}

The growing industry of nanotechnology generates a reasonable concern regarding the issue of safety and risk assessment for nanoparticles (NPs) [1-3]. This problem had created a new subcategory of toxicology, nanotoxicology [4], which is aimed to understand and explore the mechanisms of interaction between NPs and living organisms [5,6]. Despite the remarkable progress in this area, including multiple European Union (EU) and U.S. nano-specific databases and research projects, development of modern omics, and computational approaches [7], the potential influence of NPs to the aquatic environment is not fully understood and requires further investigation [8].

Cosmetics, electronic devices, pharmaceutical products, food supplements, clothing, coating, additives to some products like rubber and concrete, and other industrial and consumer products are the most common sources of engineered NPs reported in the environment [5]. NPs can enter the environment during their manufacturing, utilization, and disposal [9-11]. The potential release of NPs into the water has been estimated at up to $7 \%$ of the total global production [12].

Unique physicochemical properties of NPs provide a variety of their applications and, at the same time, make the assessment of their safety a very complex task [13]. The toxic properties of NPs mostly depend on particle size, surface area, surface chemistry, crystalline structure, method of synthesis, purity, or all together [8,14]. Moreover, the fate and behavior of NPs released in water depend on their physical, chemical, or biological transformations in the exposed environment $[8,15,16]$. Therefore, the evaluation of the aquatic toxicity of NPs requires a complex and multi-parametric study.

Traditionally, the aquatic toxicity of NPs has been tested in bioassays with different model organisms, such as bacteria [17-19], microalgae [20-22], crustaceans [23-25], sea urchin [26-28], bivalve molluscs [29,30], fish cell lines [31-33], fish [23,34,35], and amphibians [36,37]. The diversity of testing models allows us to compare the differences and similarities of toxic effects between species, which gives an opportunity to understand the potential hazards of NPs and the relationship between their toxicity mechanisms and physicochemical properties [38].

In this study, we selected bivalve molluscs as typical nearshore animals having their economic importance and ecological relevance among macrobenthic animals [39,40]. Bivalves are often used as sentinel species or environmental indicators owing to their ability to accumulate chemical contaminants, lack of mobility, and wide distribution throughout the coastal waters of the world [41,42]. Moreover, bivalve molluscs have been described as a good target group for nanotoxicology because of their ability to feed on suspensions as well as their highly developed ability for the cellular internalization of nano and microparticles $[29,43]$. The blood cells of bivalve molluscs, the hemocytes, play a key role in the innate immune response of a mussel and provide protection from foreign microorganisms and toxic substances [44]. As noted by Canesi (2012), the short-term in vitro effects of NP suspensions on mussel hemocytes, as well their mode of action, resemble those observed in mammalian phagocytes. This observation supports the hypothesis that, in bivalves, like in mammalian cells, cell-mediated immunity represents a significant target for NPs [29].

We have used a bioassay model comprising the hemocytes of three bivalve mollusc species, namely, Crenomytilus grayanus (Dunker, 1853), Modiolus modiolus (Linnaeus, 1758), and Arca boucardi (Jousseaume, 1894). The chosen species represent abundant bivalves of the Peter the Great Bay (Sea of Japan, Russia) [45]. C. grayanus, also known as Gray's mussel, lives 95-150 years attached to stable solid substrates [46]. C. grayanus is tolerant to a relatively low concentration of dissolved oxygen (3-9 mL/L) and can survive in freshwater up to $44 \mathrm{~h}$ [46]. M. modiolus, also known as the horse mussel, lives 20-45 years on rocks, boulders, gravel, pebbles, and sand, sometimes being submerged 2-3 body lengths into the sediment $[47,48]$. C. grayanus and M. modiolus are closely related bivalve 
species of the family Mytilidae, which are commonly used for heavy-metal monitoring in coastal waters of the northwestern Pacific [49,50]. It was reported that, despite a higher level of heavy metal accumulation, $M$. modiolus has a defense strategy that includes gradual detoxification and excretion of the pollutants from the organs [50]. The defense system of C. grayanus was reported as ineffective under chronic pollution because of the high load of heavy metals in the digestive gland and kidney [50]. A. boucardi is a bivalve of the family Arcidae, which lives on sand or rock-boulder bottom, often forming a joint biocenosis with C. grayanus [51].

In the bioassay with mollusc hemocytes, we used 10 types of common NPs, that is, two types of multiwalled carbon nanotubes (CNT-1, CNT-2), two types of carbon nanofibers (CNF-1, CNF-2), two types of silicon nanotubes (SNT-1, SNT-2), nanocrystals of cadmium and zinc sulfides (CdS, ZnS), gold NPs (Au-NPs), and titanium dioxide NPs $\left(\mathrm{TiO}_{2}\right)$. The toxic influence of the NPs on the hemocytes was measured by the flow cytometry method. In recent years, flow cytometry, a well-known routine tool used for vertebrate research, has been applied to bivalve immunology to study hemocyte morphology and immune-related activities [52,53].

Some toxic effects of different types of NPs on marine bivalves were previously described [30,54-56]. Despite published data, much uncertainty still exists about the relation between physicochemical properties of NPs and their toxic effects in the aquatic environment. Our study aimed to evaluate and compare the difference in cytotoxicity and cell-membrane polarization changes of the hemocytes of three bivalves exposed to 10 types of NPs.

\section{Materials and Methods}

\subsection{Nanoparticles}

Carbon nanotubes and nanofibers were synthesized and characterized in the Boreskov Institute of Catalysis (Novosibirsk, Russia) [57]. The structural features of carbon NPs ware assessed by Raman spectroscopy in our earlier report [58]. The length of the carbon nanotubes was hundreds of times larger than the diameter, and the particles could cohere into the spheres up to tens of micrometers in diameter in water suspension.

Silicon nanotubes were kindly provided by the Department of Chemistry, Inha University Republic of Korea [59]. The samples had a significantly lower ratio of length to diameter compared with carbon nanotubes.

CdS and ZnS NPs were synthesized and characterized in the University of Mining and Geology, St. Ivan Rilski (Sofia, Bulgaria) [60].

Au-NPs were synthesized by Turkevich method with reduction by citrate at $100{ }^{\circ} \mathrm{C}$ [61].

$\mathrm{TiO}_{2}$ nanopowder was purchased from Thermo Fisher Scientific (Thermo Fisher GmbH, Kandel, Germany, CAS number 1317-70-0, product number 39953). Characteristics of all the NPs used in this study are represented in Table 1.

\subsection{Hemocytes Preparation and Exposure}

The molluscs C. grayanus, M. modiolus, and A. boucardi were collected in October 2019 from Novik bay (Peter the Great Bay, Sea of Japan, Russia). Mussels were maintained for three days in an aerated $50 \mathrm{~L}$ tank filled with natural seawater. In this study, we used 16 adult specimens of each bivalve species.

The hemocytes of the molluscs were prepared using the previously described protocol [62]. Hemolymph was withdrawn from the posterior adductor of the molluscs using $0.3 \mathrm{~mL}$ syringes containing $0.3 \mathrm{M}$ sodium ethylenediaminetetraacetic acid (EDTA) salt solution for the prevention of hemocyte agglutination. The obtained hemolymph was centrifuged, and the supernatant was removed. The pellet was washed with $1 \mathrm{~mL}$ of Calcium and Magnesium Free Artificial Sea Water Solution (CMFSS) and centrifuged again. The obtained cell pellet was resuspended in sterile seawater $\left(20 \pm 2{ }^{\circ} \mathrm{C} ; \mathrm{pH}, 8.0 \pm 0.2 ;\right.$ salinity, $33 \%$ o $\pm 1 \%$ o). The volume of obtained hemocyte suspension from one mollusc was approximately $2 \mathrm{~mL}$. The counting of collected cells was carried out with flow cytometer 
CytoFLEX (Beckman Coulter, Indianapolis, IN, USA) using the software package CytExpert v.2.0. The aliquots of the hemocytes at the concentration of $8 \cdot 10^{4}$ cell $/ \mathrm{mL}$ were prepared to the bioassay.

Table 1. Characteristics of the nanoparticles used in the experiment. CNT, carbon nanotube; CNF, carbon nanofibers; SNT, silicon nanotube; NP, nanoparticle.

\begin{tabular}{|c|c|c|c|c|}
\hline Sample & Diameter nm & Surface Area $\mathrm{m}^{2} / \mathrm{g}$ & Impurities \% & Structural Features \\
\hline CNT-1 & $18-20$ & 130 & $\begin{array}{l}\mathrm{Al}-0.9 \\
\mathrm{Co}-0.3 \\
\mathrm{Fe}-0.6\end{array}$ & $\begin{array}{c}\text { many particles with defect areas } \\
\text { and opened ends of carbon } \\
\text { nanotubes }\end{array}$ \\
\hline CNT-2 & $18-20$ & 150 & $\begin{array}{l}\mathrm{Ca}-0.004 \\
\mathrm{Cl}-0.08 \\
\mathrm{Co}-0.12 \\
\mathrm{Fe}-0.2\end{array}$ & ordered nanotube structure \\
\hline CNF-1 & $90-120$ & $90-100$ & $\mathrm{Al}_{2} \mathrm{O}_{3}-0.4$ & $\begin{array}{l}\text { unordered structure, defect areas, } \\
\text { the presence of amorphous carbon }\end{array}$ \\
\hline CNF-2 & $90-120$ & 90-100 & $\begin{array}{l}\mathrm{Al}_{2} \mathrm{O}_{3}-0.4 \\
\mathrm{Ni}-3.6\end{array}$ & unordered structure, defect areas \\
\hline SNT-1 & $3-4$ & 685 & - & ordered nanotube structure \\
\hline SNT-2 & $40-45$ & 395 & - & ordered nanotube structure \\
\hline $\mathrm{CdS}$ & $5-9$ & $\mathrm{n} / \mathrm{a}$ & - & cubic crystal phase \\
\hline $\mathrm{ZnS}$ & $2.6-5.6$ & $\mathrm{n} / \mathrm{a}$ & - & cubic crystal phase \\
\hline $\mathrm{Au}-\mathrm{NPs}$ & $60-80$ & $\mathrm{n} / \mathrm{a}$ & - & spherical shape \\
\hline $\mathrm{TiO}_{2}$ & 32 & 45 & total metal-0.1 & anatase crystal structure \\
\hline
\end{tabular}

The working suspensions of the NPs were prepared for bioassays by the addition of the NPs to sterile seawater to obtain a concentration of $1000 \mathrm{mg} / \mathrm{L}$. Before each series of bioassays, the working suspensions of NPs were sonicated with ultrasound homogenizer Bandelin Sonopuls GM 3100 (Bandelin Electronic GmbH \& Co. KG, Berlin, Germany) using maximal intensity for $30 \mathrm{~min}$.

The prepared cell aliquots were replaced in 96-well plates (50 $\mu \mathrm{L}$ per well) and kept in a laboratory fridge $\left(4^{\circ} \mathrm{C}\right)$ for $30 \mathrm{~min}$. Then, the prepared and sonicated working suspensions of the NPs $(1000 \mathrm{mg} / \mathrm{L})$ were diluted with artificial seawater, and $150 \mu \mathrm{L}$ of these suspensions was added to the cells to obtain the final concentrations of 1, 10, 100, 250, 500, and $1000 \mathrm{mg} / \mathrm{L}$. Only artificial seawater was added to the group of control cells. The cells were incubated with the NPs in the fridge $\left(4{ }^{\circ} \mathrm{C}\right)$. The measurements were performed after 2, 4, and $6 \mathrm{~h}$ of the exposure. At each time point, three biological replicates of the hemocytes from each species exposed to all used NP types at each applied concentration and the control group were measured by flow cytometry.

\subsection{Flow Cytometry}

The counting of alive cells and registration of changes in cell-membrane polarization of hemocytes were carried out with flow cytometer CytoFLEX using the software package CytExpert v.2.0 (Beckman Coulter, Indianapolis, IN, USA). The toxic effects were evaluated using specific fluorescent dyes (Molecular Probes, Eugene, OR, USA). A blue laser (488 nm) of the CytoFLEX flow cytometer was chosen as a source of excitation light. The excitation laser and emission filters were selected according to the recommendations provided by the manufacturer of the dyes.

The viability of the cells was determined by staining with propidium iodide (PI) according to the standard bioassay protocol [63]. The mechanism of PI action is the incorporation between DNA or RNA base pairs, whereupon the dye increases its fluorescence intensity by 20-30 times [64]. As PI is unable to penetrate intact membranes of living cells, the cells with dramatically increased fluorescent intensity in the emission filter FL1 $(610 \mathrm{~nm})$ compared with control can be regarded as dead cells and excluded from the counting [65].

Membrane polarization of the hemocytes was assessed by a lipophilic, positively charged fluorescent dye 3,3'-dihexyloxacarbocyanine iodide $\left(\mathrm{DiOC}_{6}\right)$, which is capable of binding to 
membranes (mitochondria and endoplasmic reticulum) and other hydrophobic negatively charged cell structures [66]. In the case where the inner membranes of the cell became more electronegative compared with medium (hyperpolarization, that is, an increase in the membrane potential), the dye will be absorbed. If the membrane potential decreases and the cell becomes less electronegative compared with medium (depolarization), the dye will be removed from the cell [67]. The changes of hemocyte membrane polarization were registered as the mean fluorescent intensity of $\mathrm{DiOC}_{6}$ attached to alive cells in the emission filter FL2 (525 nm).

The measurements were performed at a flow rate of $100 \mu \mathrm{L} / \mathrm{min}$ for $30 \mathrm{~s}$. The signals of forward and side light scattering were registered in FSC and SSC emission channels, respectively, to develop the two-parameter histograms of cell distribution by size and granularity. Before the measurement, each sample of the hemocytes was stained simultaneously with PI $(15 \mu \mathrm{M})$ and $\operatorname{DiOC}_{6}(0.5 \mu \mathrm{M})$ and incubated in the dark on ice for $20 \mathrm{~min}$. The stained fixed cells were used as a negative control.

\subsection{Microscopy}

Morphological changes of hemocyte cells were observed and captured by an optical microscope Axio Observer A1 (Carl Zeiss, Oberkochen, Germany).

\subsection{Statistical Analysis}

Statistical analyses were performed using the software package GraphPad Prism 7.04 (GraphPad Software, San Diego, CA, USA). The one-way repeated measures analysis of variance (ANOVA) test was used for analysis. A value of $p \leq 0.05$ was considered statistically significant.

\section{Results}

\subsection{Cytotoxicity}

The calculated concentrations of the NPs that caused $50 \%$ inhibition $\left(\mathrm{EC}_{50}\right)$ of hemocyte viability are summarized in Appendix A (Table A1). The dynamic changes in the viability of hemocyte cells of three marine bivalve molluscs after 2, 4, and $6 \mathrm{~h}$ of exposure to the NPs are represented in Figure 1. For each tested species, only the NPs, which caused the observed changes in hemocyte viability, are represented in the figure.

Metal-based NPs (CdS, ZnS, Au-NPs, and $\mathrm{TiO}_{2}$ ) showed the highest cytotoxicity among the all tested samples. The CdS and ZnS NPs demonstrated a pronounced cytotoxic effect on the hemocytes of all three mollusc species (Figure 1a-i). Moreover, the toxicity of the ZnS NP sample for C. grayanus and A. boucardi increased significantly after $6 \mathrm{~h}$ of exposure (Figure 1c,i). The Au-NPs strongly affected the hemocytes of two species, namely M. modiolus and A. boucardi (Figure 1d-i), but did not affect A. boucardi (Figure 1a-c). The $\mathrm{TiO}_{2} \mathrm{NPs}$ caused substantial mortality of $C$. grayanus and M. modiolus hemocytes (Figure 1a-f). For $A$. boucardi, however, the $\mathrm{TiO}_{2} \mathrm{NPs}$ exhibited a relatively low cytotoxic effect, which was observed only after $6 \mathrm{~h}$ of exposition to the highest NPs concentration, $1000 \mathrm{mg} / \mathrm{L}$ (Figure 1i).

Overall, the hemocytes of M. modiolus were the most sensitive to all types of the NPs. Carbon nanotubes CNT-1 and CNT-2 demonstrated a cytotoxic effect on $M$. modiolus in all three measurements (Figure $1 \mathrm{~d}-\mathrm{f}$ ). Besides, the sample CNT-2 significantly affected $A$. boucardi hemocytes after $6 \mathrm{~h}$ of exposure (Figure 1i). Moreover, only M. modiolus showed the toxicity of SNT-1 after $6 \mathrm{~h}$ of exposure (Figure 1h).

\subsection{Membrane Polarization Changes}

The influence of the NPs on membrane polarization of C. grayanus, M. modiolus, and A. boucardi hemocytes is represented as a heatmap (Figure 2). In Figure 2, we have shown the membrane polarization changes of hemocytes after $6 \mathrm{~h}$ of exposure with the highest concentrations of the NPs 
$(250,500$, and $1000 \mathrm{mg} / \mathrm{L})$. The mean fluorescence intensity of $\mathrm{DiOC}_{6}$ attached to the cells of the control group was taken as $100 \%$.
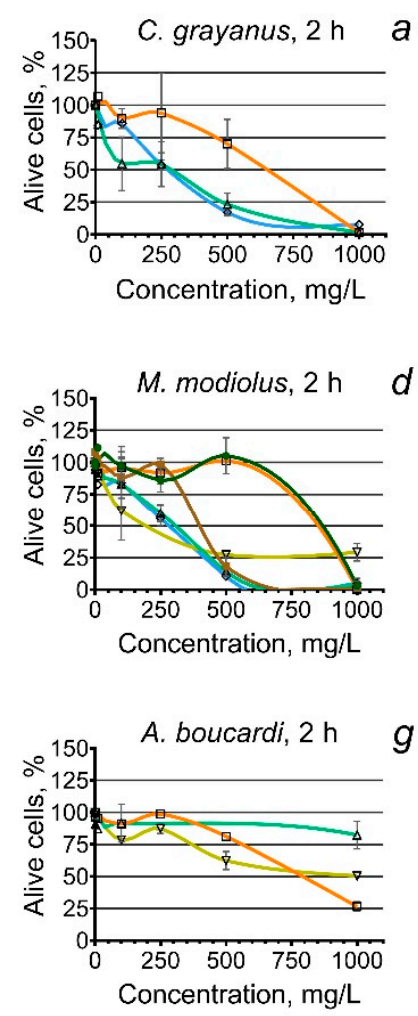

C. grayanus, $4 \mathrm{~h}$
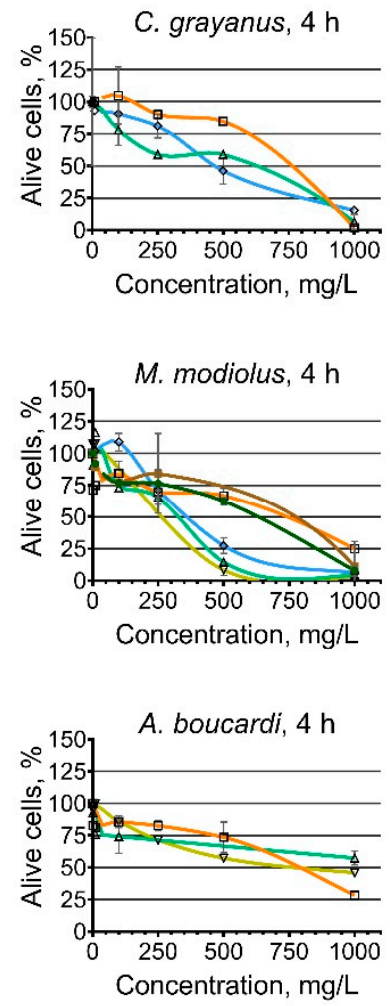

$b$

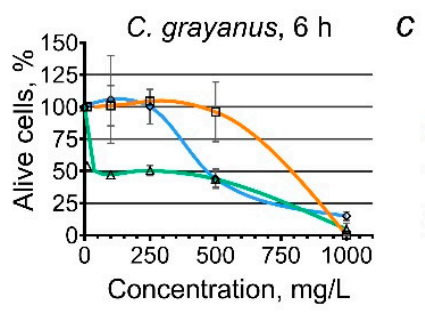

$\square \mathrm{CdS}$

$\triangle \mathrm{ZnS}$

$\diamond \mathrm{TiO}_{2}$

e

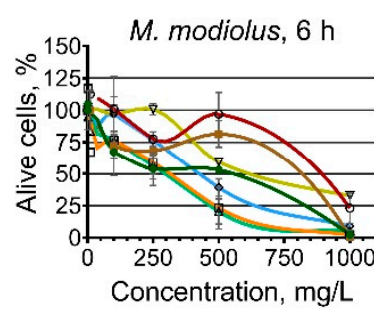

CNT-1

CNT-2

- SNT-1

$\square \mathrm{CdS}$

$\Delta \mathrm{ZnS}$

$\nabla$ Au-NPs

$\diamond \mathrm{TiO}_{2}$

h

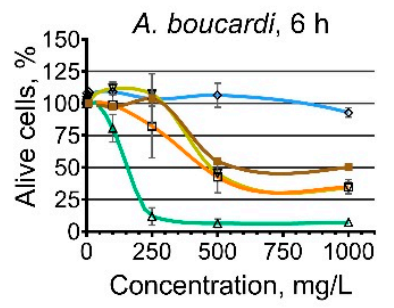

CNT-2

$\square \mathrm{CdS}$

$\Delta \mathrm{ZnS}$

$\boldsymbol{\nabla}$ Au-NPs

$\diamond \mathrm{TiO}_{2}$

Figure 1. The viability of hemocyte cells of the molluscs C. grayanus, M. modiolus, and A. boucardi after the treatment with the nanoparticles (NPs); $(\mathbf{a}-\mathbf{c})$ the changes in the total number of alive $C$. grayanus hemocytes after 2,4 , and 6 h exposure to the NPs, respectively; $(\mathbf{d}-\mathbf{f})$ the changes in the total number of alive M. modiolus hemocytes after 2, 4, and $6 \mathrm{~h}$ exposure to the NPs, respectively; and (g-i) the changes in the total number of alive $A$. boucardi hemocytes after 2,4 , and $6 \mathrm{~h}$ exposure to the NPs, respectively. $\mathrm{CNT}$, carbon nanotube; SNT, silicon nanotube.

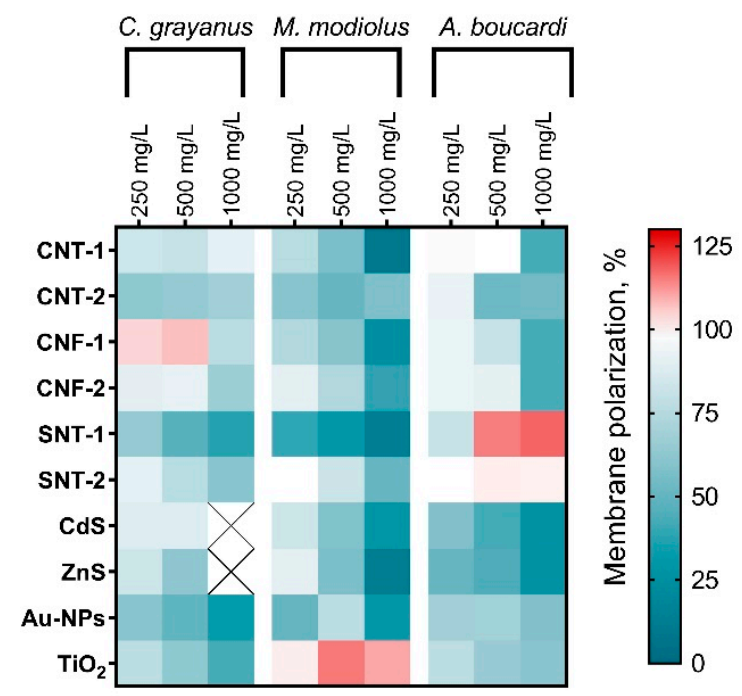

Figure 2. The changes of membrane polarization of $C$. grayanus, M. modiolus, and A. boucardi hemocytes after $6 \mathrm{~h}$ of the treatment with the NPs at concentrations of 250,500, and $1000 \mathrm{mg} / \mathrm{L}$. CNT, carbon nanotube; CNF, carbon nanofibers; SNT, silicon nanotube; NP, nanoparticle. 
For most of the tested NPs, we can notice the dose-dependent membrane depolarization. The sensitivity and reaction differed between the species and even hyperpolarization could be noted in some cases. The highest membrane depolarization under the influence of all NP samples (except $\mathrm{TiO}_{2}$ ) was demonstrated by the hemocytes of $\mathrm{M}$. modiolus at the concentration of $1000 \mathrm{mg} / \mathrm{L}$.

All carbon-based NPs (CNT-1, CNT-2, CNF-1, and CNF-2) had the lowest influence on A. boucardi hemocyte membrane polarization at the concentration of $250 \mathrm{mg} / \mathrm{L}$, but significant depolarization was recorded at $1000 \mathrm{mg} / \mathrm{L}$.

Silicon nanotubes SNT-1 caused the highest membrane depolarization of C. grayanus and M. modiolus hemocytes. At the same time, A. boucardi responded with hyperpolarization of hemocyte membranes under the influence of the sample SNT-1 and demonstrated no response to the influence of the sample SNT-2.

Among the metal-based NPs, the most pronounced membrane depolarization was caused by the influence of CdS and ZnS NPs. Depolarization of C. grayanus hemocyte membranes was not registered for these samples at $1000 \mathrm{mg} / \mathrm{L}$ as almost all the cells were dead (Figure 1a). Au-NPs decreased membrane polarization of C. grayanus and M. modiolus hemocytes higher than the polarization of A. boucardi cells. $\mathrm{TiO}_{2}$ caused membrane hyperpolarization of $M$. modiolus cells (Figure 2).

\subsection{Visual Observation}

The observed changes in the hemocyte cells revealed a cytotoxic effect, according to the data in Figure 1, represented in Appendix B. The cells of C. grayanus exposed to $1000 \mathrm{mg} / \mathrm{L}$ of the samples $\mathrm{CdS}, \mathrm{ZnS}$, and $\mathrm{TiO}_{2}$ over $6 \mathrm{~h}$ are shown in Figure A1. The hemocytes of M. modiolus exposed to CNT-1, CNT-2, SNT-1, CdS, ZnS, Au-NPs, and $\mathrm{TiO}_{2}$ at the same conditions are presented in Figure A2. The changes of $A$. boucardi cells after $6 \mathrm{~h}$ of treatment with CNT-2, CdS, ZnS, Au-NPs, and TiO 2 are shown in Figure A3.

High mortality and the residuals of dead C. grayanus hemocytes exposed to ZnS NPs are represented in Figure A1c. A similar observation was noticed for the cells of M. modiolus exposed to Au-NPs (Figure A2g) and for the cells of A. boucardi exposed to ZnS NPs (Figure A3d).

\section{Discussion}

The available literature confirmed the applicability of bivalve mollusc species as a reliable model for both in vivo and in vitro bioassays in nanotoxicology $[29,30]$. However, the species chosen in our study are not commonly used for NP toxicity evaluation $[68,69]$. In this study, we have identified the differences between the influence of 10 types of carbon, silicon, and metal-based NPs on hemocytes of three typical marine mussels of the Sea of Japan, namely, C. grayanus, M. modiolus, and A. boucardi [45].

\subsection{Toxicity of Carbon Nanotubes and Nanofibers on Bivalve Molluscs}

The absence of any visible cytotoxic influence of carbon nanofibers CNF-1 and CNF-2 on hemocytes of all the tested species (Figure 1) could be because of the lower bioavailability of the samples according to their surface and structural properties [70,71]. Moreover, the dose- and time-dependent increase in the mortality for M. modiolus exposed to carbon nanotubes CNT-1 and CNT-1 (Figure 1d-f), and the increase in the mortality for A. boucardi exposed to CNT-2 (Figure 1i), are apparently linked with the differences in the structure of used carbon NPs (Table 1). At the same time, there was no correlation between registered toxic effects and the composition of chemical impurities in the samples. A similar observation was previously reported for hemocytes of the mussel M. edulis exposed to carbon nanotubes and carbon nanofibers [72]. Furthermore, the higher toxic effect of single-walled carbon nanotubes in comparison with multi-walled carbon nanotubes was observed for the cells of Mytilus sp. [73], which confirms the higher toxicity of more hydrophilic carbon NPs. In our early work with the same samples of NPs tested on four microalgae species [74], we had shown that surface hydrophobicity of the sample and its affinity to a cell wall of marine organisms play a key role in the level of carbon NP aquatic toxicity. Therefore, it seems that more hydrophilic carbon nanotubes CNT-1 and CNT-1 
generated higher mechanical damage to the hemocyte cells compared with hydrophobic and less ordered carbon nanofibers CNF-1 and CNF-2. In particular, the reliability of this proposition can be seen for the M. modiolus hemocytes (Figure 1d,e), as this species proved to be the most sensitive used test-object.

Moreover, the sensitivity of M. modiolus hemocytes exposed to the NPs was expressed in terms of the highest membrane depolarization as compared with the other two species (Figure 2). All the tested samples of carbon NPs affected membrane polarization of hemocytes of all used species in a dose-dependent manner. The reduction of the membrane potential was previously described as an indicator of pre-apoptotic processes and as a marker of early sub-lethal toxicity [75]. The tolerance of C. grayanus cells to the influence of the tested carbon NPs (Figure 1a-c) correlates with the lowest level of membrane depolarization as compared with the other two species (Figure 2). Besides, A. boucardi revealed a cytotoxic response after $6 \mathrm{~h}$ of exposure to CNT-2 NPs (Figure 1i) and demonstrated a higher membrane depolarization at the concentrations of 500 and $1000 \mathrm{mg} / \mathrm{L}$ (Figure 2).

These observations allow us to hypothesize that a longer exposure of hemocytes with carbon NPs could lead to further membrane depolarization and, finally, could result in cytotoxicity. This is an important foundation for prolonged exposure studies in the future.

\subsection{Toxicity of Silicon Nanotubes on Bivalve Molluscs}

Only the hemocytes of $M$. modiolus demonstrated a cytotoxic response under the influence of SNT-1 after $6 \mathrm{~h}$ of exposure (Figure 1f). The higher toxicity of SNT-1 as compared with SNT-2 NPs is correlated with a smaller size and a significantly more developed surface area (Table 1). Higher toxicity of smaller particles with a bigger surface area is one of the key points in particle toxicology [76].

The analysis of changes in hemocyte membrane polarization showed that SNT-1 NPs had a more significant effect on membrane charge of all three mussel species as compared with SNT-2 NPs (Figure 2). Interestingly, the hemocytes of $A$. boucardi responded with dose-dependent membrane hyperpolarization, which is possibly because of the early activation of several cell death pathways $[77,78]$. The most pronounced membrane depolarization was observed for the M. modiolus cells exposed to SNT-1 owing to their smaller size (Figure 2). These observations agree with the registered cytotoxic effect of the SNT-1 NPs (Figure 1f).

According to the cytotoxicity data (Figure 1f), we can emphasize the similarity between the shapes of viability-curves for hemocytes of M. modiolus exposed to carbon nanotubes (CNT-1 and CNT-2) and silicon nanotube sample (SNT-1). These findings suggest a similar mode of toxic action for carbon and silicon nanotubes, which is most probably expressed in the mechanical influence of the particles to the cells.

\subsection{Toxicity of Metal-Based Nanoparticles on Bivalve Molluscs}

\subsubsection{Metal Sulfide Nanocrystals}

Metal sulfide nanocrystals, that is, CdS and ZnS, were previously described as highly toxic NPs for the aquatic organisms [79-81] because of their small size, photoactivity under visible and UV-light, and possible release of toxic metal ions as a result of nanocrystal photocorrosion in water $[82,83]$. We registered dose- and time-dependent cytotoxicity of CdS and ZnS NPs to hemocytes of all three bivalve species (Figure 1). A significant increase of ZnS NP toxicity could be observed at $6 \mathrm{~h}$ measurements for C. grayanus (Figure 1c) and A. boucardi (Figure 1i). The observed effect is possibly linked with the lower stability of $\mathrm{ZnS}$ nanocrystals in water $\left(\log \mathrm{K}_{\mathrm{s} 0},-26.02\right)$ as compared with that of $\mathrm{CdS}\left(\log \mathrm{K}_{\mathrm{s} 0},-31.42\right)$, which results in nanocrystal solubility (e.g., more $\mathrm{Zn}^{2+}$ and $\mathrm{S}^{2-}$ ions can be formed in solution) [83]. The higher aquatic toxicity of $\mathrm{Zn}^{2+}$ ions as compared with the NP form was described in previous works $[55,84]$. Moreover, the superior toxicity of CdS and ZnS NPs might be the result of a relatively smaller size as compared with the other NPs (Table 1). 
Significant membrane depolarization of hemocytes exposed to CdS and ZnS NPs (Figure 2) is probably caused by a high photoactivity of metal sulfide nanocrystals [60], which facilitates the generation of reactive oxygen species (ROS) in the media and, finally, leads to the oxidative damage and general cellular metabolic disorders $[85,86]$. Similarly, it was previously described that $\mathrm{Zn}^{2+}$ ions lead to intracellular ROS generation and cause mitochondrial membrane depolarization and dysfunction [87].

Despite the high level of toxicity registered for CdS and ZnS NPs, there are still many unanswered questions about the correlation between the aquatic toxicity of NPs and parameters such as light irradiation, ROS formation, and transformation of the NPs. Further research is needed to examine more closely the links between particle characteristics and their toxic influence on aquatic organisms.

\subsubsection{Titanium Dioxide Nanoparticles}

$\mathrm{TiO}_{2} \mathrm{NPs}$ are used in a variety of consumer products and are widely applied in environmental purification $[88,89]$. Previous studies have demonstrated that the anatase crystal form of $\mathrm{TiO}_{2} \mathrm{NPs}$ is significantly more toxic than the rutile particles [90]. Contrary to C. grayanus and A. boucardi cells, the $M$. modiolus hemocytes responded with membrane hyperpolarization under the influence of $\mathrm{TiO}_{2}$ NPs (Figure 2). Such a response could be because of the ROS generation by photoactive $\mathrm{TiO}_{2} \mathrm{NPs}_{\text {[91] }}$ and further oxidative disorder. The differences observed in the toxic effects of these NPs between the tested species could be associated with the dissimilarity in their antioxidative defense systems, as previously shown for several bivalves [92]. The A. boucardi hemocytes responded to $\mathrm{TiO}_{2} \mathrm{NPs}$ only after $6 \mathrm{~h}$ of exposure at the highest concentrations (Figure 1i). Therefore, it can be assumed that the longer exposure of $\mathrm{TiO}_{2} \mathrm{NPs}$ could cause a significant increase in a toxic effect on the hemocytes of tested mollusc species. A further study should assess the long-term influence of $\mathrm{TiO}_{2} \mathrm{NPs}$ on marine bivalves.

\subsubsection{Gold Nanoparticles}

Gold NPs have promising applications in medicine, biology, and chemistry [93]. Previous work did not show short-term and sub-chronic toxicity of citrate-stabilized Au-NPs on marine bivalve R. philippinarum [94]. Another study demonstrated the accumulation of Au-NPs in M. edulis bivalve mollusc and oxidative stress-related toxicity [95]. Our results have demonstrated the cytotoxic influence of Au-NPs on hemocytes of M. modiolus (Figure 1d-f) and A. boucardi (Figure 1g-h). Interestingly, the hemocytes of $C$. grayanus revealed tolerance to Au-NPs after short-term exposure (Figure 1a-c), but showed significant membrane depolarization (Figure 2).

\section{Conclusions}

The highest aquatic toxicity was registered for metal-based NPs, which caused cytotoxicity to the hemocytes of all the studied bivalve species. Our results demonstrated that more hydrophilic carbon nanotubes CNT-1 and CNT-1 generated higher mechanical damage to bivalve hemocyte cells compared with hydrophobic and less ordered carbon nanofibers CNF-1 and CNF-2. The higher toxicity of SNT-1 as compared with SNT-2 NPs is correlated with a smaller size and a significantly more developed surface area of the sample. Moreover, the similarity between the shapes of viability-curves for the hemocytes exposed to carbon nanotubes and silicon nanotubes suggest a similar mode of toxic action for carbon and silicon nanotubes, which is most probably expressed in the mechanical influence of the particles to the cells. We believe that the results of this short-term in vitro bioassay will lay the foundations for further understanding of the risks associated with NPs and provide guidance for choosing bivalve molluscs as the tested species for such risk assessment studies in the area of aquatic nanotoxicology. This finding, while preliminary, represents an interesting case for further research. We intend to extend this study by applying indicators of oxidative stress and the implementation of long-term exposure. 
Author Contributions: Conceptualization and design, K.G., A.Z., and A.A.; flow cytometry, A.S., I.K., and V.C.; microscopy, V.C. and A.A.; analysis and writing of the manuscript, K.P.; project administration, K.G. All authors have read and agreed to the published version of the manuscript.

Funding: This research was funded by RFBR, project number 19-05-50010.

Acknowledgments: The authors would like to thank the staff team of Far Eastern Federal University Center of Collective Use Interdepartmental Center for Analytical Control of the Environment for their dedicated involvement in this study.

Conflicts of Interest: The authors declare no conflict of interest. 


\section{Appendix A}

Table A1. Calculated values of $\mathrm{EC}_{50}$ for viability of the hemocytes after the exposure to the nanoparticles, $\mathrm{mg} / \mathrm{L}$.

\begin{tabular}{|c|c|c|c|c|c|c|c|c|c|}
\hline \multirow{2}{*}{ NPs } & \multicolumn{3}{|c|}{ C. grayanus $^{1}$} & \multicolumn{3}{|c|}{ M. modiolus ${ }^{2}$} & \multicolumn{3}{|c|}{ A. boucardi $i^{3}$} \\
\hline & $2 \mathrm{~h}$ & $4 \mathrm{~h}$ & $6 \mathrm{~h}$ & $2 \mathrm{~h}$ & $4 \mathrm{~h}$ & $6 \mathrm{~h}$ & $2 \mathrm{~h}$ & $4 \mathrm{~h}$ & $6 \mathrm{~h}$ \\
\hline CNT-1 & $\mathrm{n} / \mathrm{a}$ & $\mathrm{n} / \mathrm{a}$ & $\mathrm{n} / \mathrm{a}$ & 864.6 & $\begin{array}{c}512.2 \\
(366.1-670.9)\end{array}$ & $\begin{array}{c}241.5 \\
(132.9-382.5)\end{array}$ & $\mathrm{n} / \mathrm{a}$ & $\mathrm{n} / \mathrm{a}$ & $\mathrm{n} / \mathrm{a}$ \\
\hline CNT-2 & $\mathrm{n} / \mathrm{a}$ & $\mathrm{n} / \mathrm{a}$ & $\mathrm{n} / \mathrm{a}$ & 471.1 & $\begin{array}{c}447.3 \\
(319.5-672.6)\end{array}$ & $\begin{array}{c}284.7 \\
(136.7-459.9)\end{array}$ & $\mathrm{n} / \mathrm{a}$ & $\mathrm{n} / \mathrm{a}$ & 752.6 \\
\hline CNF-1 & $\mathrm{n} / \mathrm{a}$ & $\mathrm{n} / \mathrm{a}$ & $\mathrm{n} / \mathrm{a}$ & $\mathrm{n} / \mathrm{a}$ & $\mathrm{n} / \mathrm{a}$ & n/a & $\mathrm{n} / \mathrm{a}$ & $\mathrm{n} / \mathrm{a}$ & $\mathrm{n} / \mathrm{a}$ \\
\hline CNF-2 & $\mathrm{n} / \mathrm{a}$ & $\mathrm{n} / \mathrm{a}$ & $\mathrm{n} / \mathrm{a}$ & $\mathrm{n} / \mathrm{a}$ & $\mathrm{n} / \mathrm{a}$ & $\mathrm{n} / \mathrm{a}$ & $\mathrm{n} / \mathrm{a}$ & $\mathrm{n} / \mathrm{a}$ & $\mathrm{n} / \mathrm{a}$ \\
\hline SNT-1 & $\mathrm{n} / \mathrm{a}$ & $\mathrm{n} / \mathrm{a}$ & $\mathrm{n} / \mathrm{a}$ & $\mathrm{n} / \mathrm{a}$ & $\mathrm{n} / \mathrm{a}$ & $\begin{array}{c}606.8 \\
(387.3-853.8)\end{array}$ & $\mathrm{n} / \mathrm{a}$ & $\mathrm{n} / \mathrm{a}$ & $\mathrm{n} / \mathrm{a}$ \\
\hline SNT-2 & $\mathrm{n} / \mathrm{a}$ & $\mathrm{n} / \mathrm{a}$ & $\mathrm{n} / \mathrm{a}$ & $\mathrm{n} / \mathrm{a}$ & $\mathrm{n} / \mathrm{a}$ & $\mathrm{n} / \mathrm{a}$ & $\mathrm{n} / \mathrm{a}$ & $\mathrm{n} / \mathrm{a}$ & $\mathrm{n} / \mathrm{a}$ \\
\hline $\mathrm{CdS}$ & 616.7 & 620.8 & 637.9 & 827.3 & $\begin{array}{c}530.3 \\
(388.4-837.6)\end{array}$ & $\begin{array}{c}212.4 \\
(136.3-300.0)\end{array}$ & $\begin{array}{c}752.6 \\
(706.8-800.8)\end{array}$ & $\begin{array}{c}662.9 \\
(507.7-1233)\end{array}$ & $\begin{array}{c}538.2 \\
(383.9-824.2)\end{array}$ \\
\hline $\mathrm{ZnS}$ & $\begin{array}{c}275.5 \\
(157.0-409.2)\end{array}$ & $\begin{array}{c}277.4 \\
(90.4-552.2)\end{array}$ & $\begin{array}{c}143.4 \\
(58.0-266.9)\end{array}$ & $\begin{array}{c}268.6 \\
(232.3-305.8)\end{array}$ & $\begin{array}{c}283.5 \\
(218.9-349.0)\end{array}$ & $\begin{array}{c}251.2 \\
(178.1-321.7)\end{array}$ & $\mathrm{n} / \mathrm{a}$ & $\begin{array}{c}157.8 \\
(83.6-270.4)\end{array}$ & $\begin{array}{c}147.9 \\
(123.8-172.0)\end{array}$ \\
\hline $\mathrm{Au}-\mathrm{NPs}$ & $\mathrm{n} / \mathrm{a}$ & $\mathrm{n} / \mathrm{a}$ & $\mathrm{n} / \mathrm{a}$ & $\mathrm{n} / \mathrm{a}$ & 591.8 & $\begin{array}{c}560.5 \\
(528.3-591.9)\end{array}$ & $\mathrm{n} / \mathrm{a}$ & 766.8 & $\begin{array}{c}597.1 \\
(482.4-758.7)\end{array}$ \\
\hline $\mathrm{TiO}_{2}$ & $\begin{array}{c}343.6 \\
(234.3-518.0)\end{array}$ & $\begin{array}{c}368.1 \\
(306.9-433.9)\end{array}$ & $\begin{array}{c}338.8 \\
(210.5-476.5)\end{array}$ & $\begin{array}{c}333.6 \\
(253.0-448.5)\end{array}$ & $\begin{array}{c}354.0 \\
(317.6-394.7)\end{array}$ & $\begin{array}{c}376.6 \\
(297.4-455.1)\end{array}$ & $\mathrm{n} / \mathrm{a}$ & $\mathrm{n} / \mathrm{a}$ & $\mathrm{n} / \mathrm{a}$ \\
\hline
\end{tabular}

$95 \%$ confidence limits presented in the parentheses. $\mathrm{n} / \mathrm{a}$-measured effect was not observed even at the highest concentrations of the sample $(1000 \mathrm{mg} / \mathrm{L}) .{ }^{1} p=0.0078 .{ }^{2} p=0.0267$. ${ }^{3} p<0.0001$. 


\section{Appendix B}

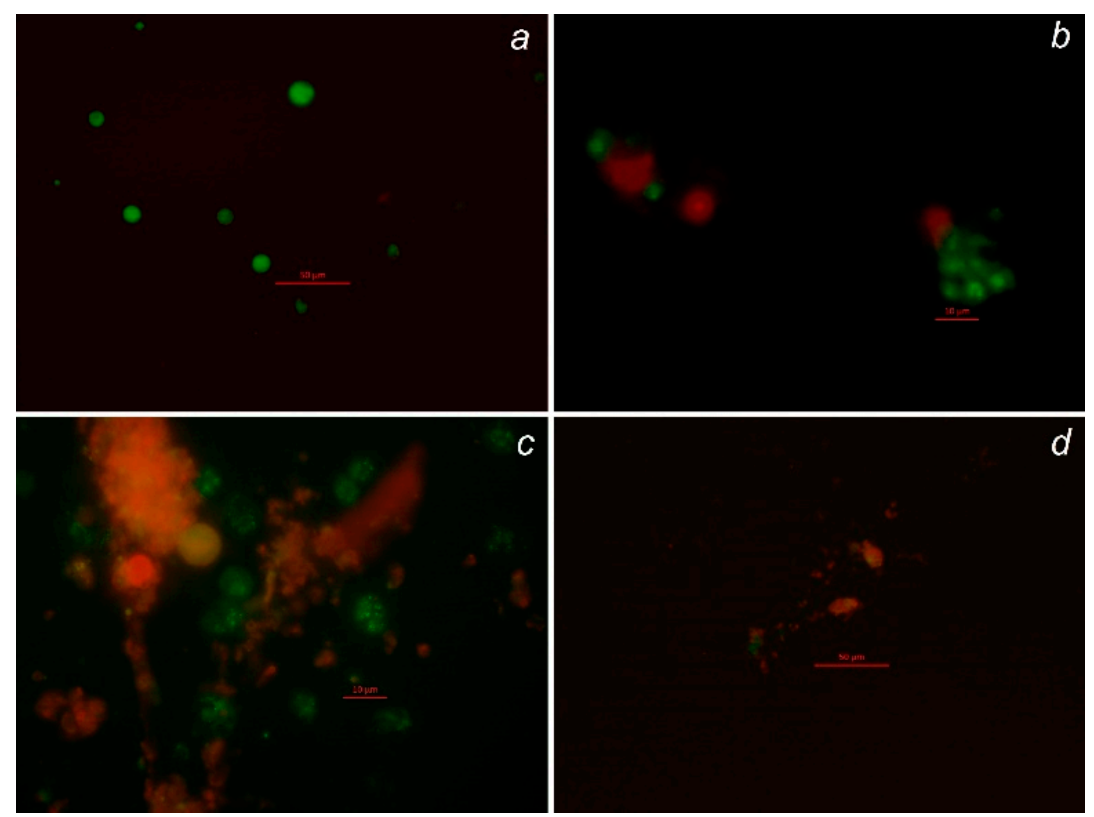

Figure A1. The hemocyte cells of the mollusc C. grayanus after $6 \mathrm{~h}$ of exposure with the NPs at the concentration of $1000 \mathrm{mg} / \mathrm{L}$ : (a) control; (b) CdS; (c) ZnS; and (d) $\mathrm{TiO}_{2}$.

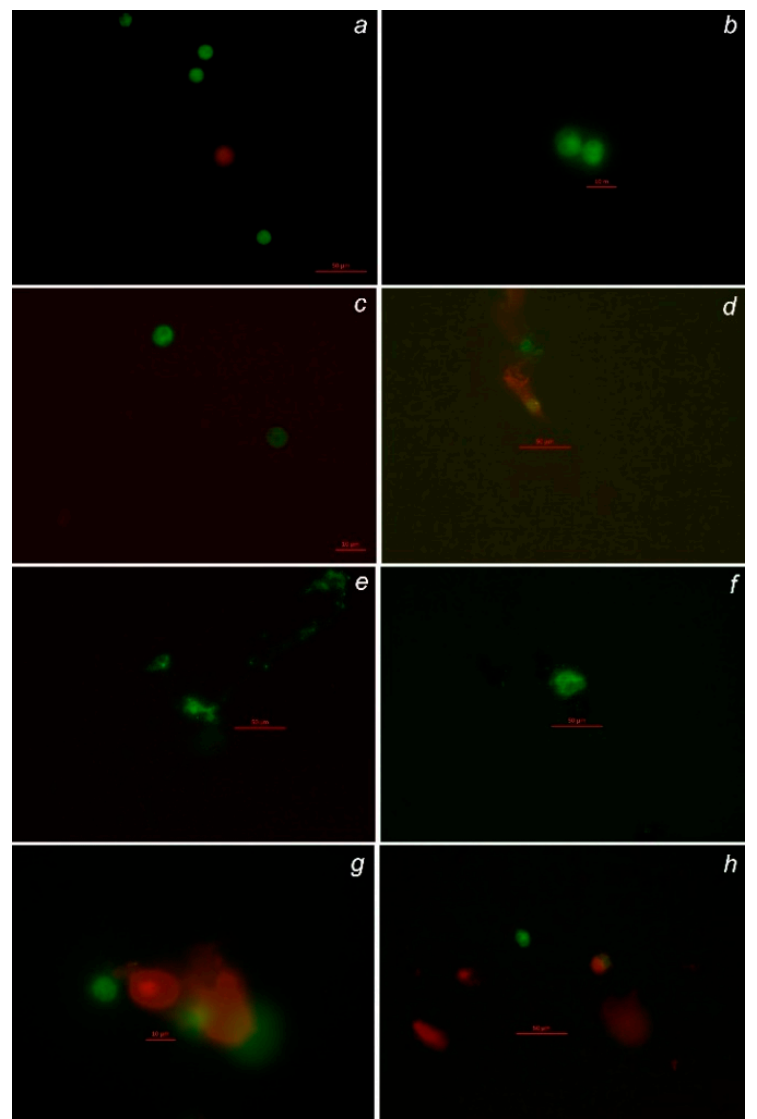

Figure A2. The hemocyte cells of the mollusc M.modiolus after $6 \mathrm{~h}$ of exposure with the NPs at the concentration of $1000 \mathrm{mg} / \mathrm{L}$ : (a) control; (b) CNT-1; (c) CNT-2; (d) SNT-1; (e) CdS; (f) ZnS; (g) Au-NPs; and (h) $\mathrm{TiO}_{2}$. 


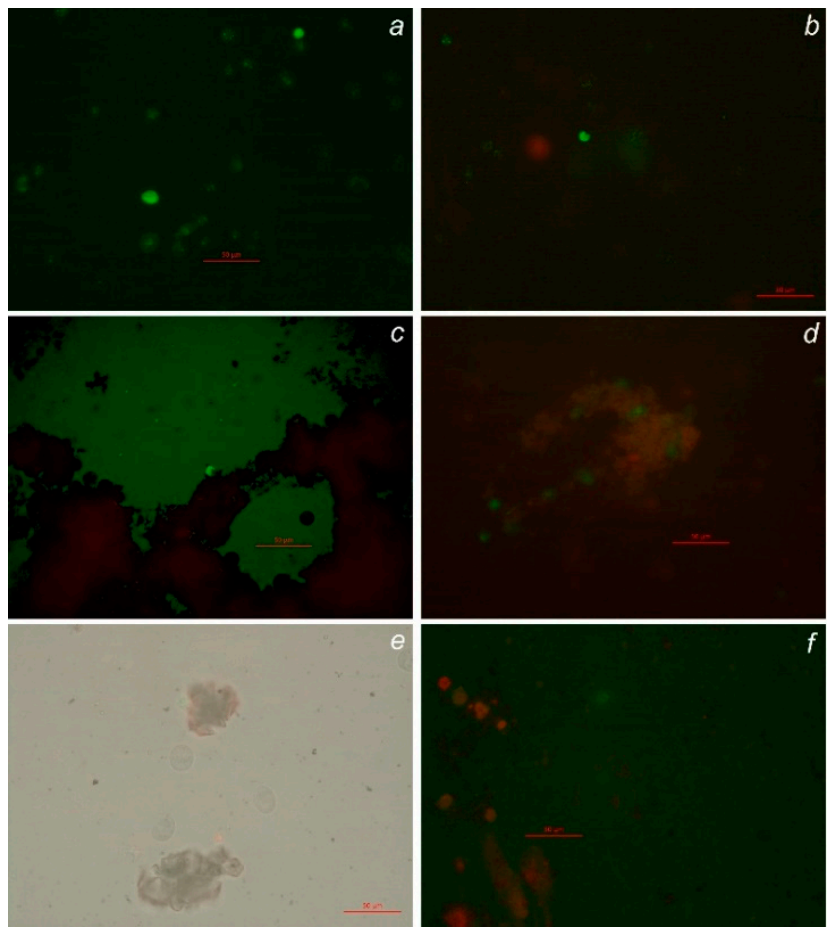

Figure A3. The hemocyte cells of the mollusc A.boucardi after $6 \mathrm{~h}$ of exposure with the NPs at the concentration of 1000 mg/L: (a) control; (b) CNT-2; (c) CdS; (d) ZnS; (e) Au-NPs; and (f) $\mathrm{TiO}_{2}$.

\section{References}

1. Bakand, S.; Hayes, A. Toxicological considerations, toxicity assessment, and risk management of inhaled nanoparticles. Int. J. Mol. Sci. 2016, 17, 929. [CrossRef] [PubMed]

2. Guinée, J.B.; Heijungs, R.; Vijver, M.G.; Peijnenburg, W.J. Setting the stage for debating the roles of risk assessment and life-cycle assessment of engineered nanomaterials. Nat. Nanotechnol. 2017, 12, 727. [CrossRef] [PubMed]

3. Oliveira, M.L.; Izquierdo, M.; Querol, X.; Lieberman, R.N.; Saikia, B.K.; Silva, L.F. Nanoparticles from construction wastes: A problem to health and the environment. J. Clean. Prod. 2019, 219, 236-243. [CrossRef]

4. Donaldson, K.; Stone, V.; Tran, C.L.; Kreyling, W.; Borm, P.J.A. Nanotoxicology. Occup. Environ. Med. 2004, 61, 727-728. [CrossRef] [PubMed]

5. Jeevanandam, J.; Barhoum, A.; Chan, Y.S.; Dufresne, A.; Danquah, M.K. Review on nanoparticles and nanostructured materials: History, sources, toxicity and regulations. Beilstein J. Nanotechnol. 2018, 9 , 1050-1074. [CrossRef] [PubMed]

6. Singh, A.V.; Laux, P.; Luch, A.; Sudrik, C.; Wiehr, S.; Wild, A.M.; Santomauro, G.; Bill, J.; Sitti, M. Review of emerging concepts in nanotoxicology: Opportunities and challenges for safer nanomaterial design. Toxicol. Mech. Methods 2019, 29, 378-387. [CrossRef]

7. Pikula, K.; Zakharenko, A.; Chaika, V.; Kirichenko, K.; Tsatsakis, A.; Golokhvast, K. Risk assessments in nanotoxicology: Bioinformatics and computational approaches. Curr. Opin. Toxl. 2020, 19, 1-6. [CrossRef]

8. Turan, N.B.; Erkan, H.S.; Engin, G.O.; Bilgili, M.S. Nanoparticles in the aquatic environment: Usage, properties, transformation and toxicity-A review. Process Saf. Environ. Prot. 2019, 130, 238-249. [CrossRef]

9. Giese, B.; Klaessig, F.; Park, B.; Kaegi, R.; Steinfeldt, M.; Wigger, H.; von Gleich, A.; Gottschalk, F. Risks, release and concentrations of engineered nanomaterial in the environment. Sci. Rep. 2018, 8, 1-8. [CrossRef]

10. Gottschalk, F.; Sun, T.; Nowack, B. Environmental concentrations of engineered nanomaterials: Review of modeling and analytical studies. Environ. Pollut. 2013, 181, 287-300. [CrossRef]

11. Bundschuh, M.; Filser, J.; Lüderwald, S.; McKee, M.S.; Metreveli, G.; Schaumann, G.E.; Schulz, R.; Wagner, S. Nanoparticles in the environment: Where do we come from, where do we go to? Environ. Sci. Eur. 2018, 30, 1-17. [CrossRef] [PubMed] 
12. Keller, A.A.; McFerran, S.; Lazareva, A.; Suh, S. Global life cycle releases of engineered nanomaterials. J. Nanopart. Res. 2013, 15, 1692. [CrossRef]

13. Singh, A.K. Engineered Nanoparticles: Structure, Properties and Mechanisms of Toxicity; Academic Press: London, UK, 2015; pp. 296-506.

14. Shvedova, A.A.; Kagan, V.E.; Fadeel, B. Close encounters of the small kind: Adverse effects of man-made materials interfacing with the nano-cosmos of biological systems. Annu. Rev. Pharmacol. Toxicol. 2010, 50, 63-88. [CrossRef] [PubMed]

15. Lead, J.R.; Batley, G.E.; Alvarez, P.J.J.; Croteau, M.N.; Handy, R.D.; McLaughlin, M.J.; Judy, J.D.; Schirmer, K. Nanomaterials in the environment: Behavior, fate, bioavailability, and effects: An updated review. Environ. Toxicol. Chem. 2018, 37, 2029-2063. [CrossRef]

16. Biswas, J.K.; Sarkar, D. Nanopollution in the aquatic environment and ecotoxicity: No nano issue! Curr. Pollut. Rep. 2019, 5, 4-7. [CrossRef]

17. Tyagi, N.; Kumar, A. Understanding effect of interaction of nanoparticles and antibiotics on bacteria survival under aquatic conditions: Knowns and unknowns. Environ. Res. 2020, 181, 108945. [CrossRef]

18. Maksimova, Y.G. Microorganisms and carbon nanotubes: Interaction and Applications (Review). Appl. Biochem. Microbiol. 2019, 55, 1-12. [CrossRef]

19. Vimbela, G.V.; Ngo, S.M.; Fraze, C.; Yang, L.; Stout, D.A. Antibacterial properties and toxicity from metallic nanomaterials. Int. J. Nanomed. 2017, 12, 3941-3965. [CrossRef]

20. Deniel, M.; Errien, N.; Daniel, P.; Caruso, A.; Lagarde, F. Current methods to monitor microalgae-nanoparticle interaction and associated effects. Aquat. Toxicol. 2019, 217, 105311. [CrossRef]

21. Wang, F.; Guan, W.; Xu, L.; Ding, Z.Y.; Ma, H.L.; Ma, A.Z.; Terry, N. Effects of nanoparticles on algae: Adsorption, distribution, ecotoxicity and fate. Appl. Sci-Basel 2019, 9, 1534. [CrossRef]

22. Tang, Y.L.; Xin, H.J.; Yang, F.; Long, X. A historical review and bibliometric analysis of nanoparticles toxicity on algae. J. Nanopart. Res. 2018, 20, 92. [CrossRef]

23. Callaghan, N.I.; MacCormack, T.J. Ecophysiological perspectives on engineered nanomaterial toxicity in fish and crustaceans. Comp. Biochem. Physiol. Part C Toxicol. Pharmacol. 2017, 193, 30-41. [CrossRef] [PubMed]

24. Hou, J.; Zhou, Y.; Wang, C.J.; Li, S.G.; Wang, X.K. Toxic effects and molecular mechanism of different types of silver nanoparticles to the aquatic crustacean daphnia magna. Environ. Sci. Technol. 2017, 51, 12868-12878. [CrossRef] [PubMed]

25. Wu, F.; Bortvedt, A.; Harper, B.J.; Crandon, L.E.; Harper, S.L. Uptake and toxicity of CuO nanoparticles to Daphnia magna varies between indirect dietary and direct waterborne exposures. Aquat. Toxicol. 2017, 190, 78-86. [CrossRef]

26. Gambardella, C.; Ferrando, S.; Gatti, A.M.; Cataldi, E.; Ramoino, P.; Aluigi, M.G.; Faimali, M.; Diaspro, A.; Falugi, C. Review: Morphofunctional and biochemical markers of stress in sea urchin life stages exposed to engineered nanoparticles. Environ. Toxicol. 2016, 31, 1552-1562. [CrossRef]

27. Gambardella, C.; Morgana, S.; Di Bari, G.; Ramoino, P.; Bramini, M.; Diaspro, A.; Falugi, C.; Faimali, M. Multidisciplinary screening of toxicity induced by silica nanoparticles during sea urchin development. Chemosphere 2015, 139, 486-495. [CrossRef]

28. Grassi, G.; Landi, C.; Della Torre, C.; Bergami, E.; Bini, L.; Corsi, I. Proteomic profile of the hard corona of charged polystyrene nanoparticles exposed to sea urchin Paracentrotus lividus coelomic fluid highlights potential drivers of toxicity. Environ. Sci. Nano 2019, 6, 2937-2947. [CrossRef]

29. Canesi, L.; Ciacci, C.; Fabbri, R.; Marcomini, A.; Pojana, G.; Gallo, G. Bivalve molluscs as a unique target group for nanoparticle toxicity. Mar. Environ. Res. 2012, 76, 16-21. [CrossRef]

30. De Marchi, L.; Coppola, F.; Soares, A.; Pretti, C.; Monserrat, J.M.; della Torre, C.; Freitas, R. Engineered nanomaterials: From their properties and applications, to their toxicity towards marine bivalves in a changing environment. Environ. Res. 2019, 178, 108683. [CrossRef]

31. Samadder, A.; Tarafdar, D.; Das, R.; Khuda-Bukhsh, A.R.; Abraham, S.K. Efficacy of nanoencapsulated pelargonidin in ameliorating pesticide toxicity in fish and L6 cells: Modulation of oxidative stress and signalling cascade. Sci. Total Environ. 2019, 671, 466-473. [CrossRef]

32. Kalman, J.; Merino, C.; Fernandez-Cruz, M.L.; Navas, J.M. Usefulness of fish cell lines for the initial characterization of toxicity and cellular fate of graphene-related materials (carbon nanofibers and graphene oxide). Chemosphere 2019, 218, 347-358. [CrossRef] [PubMed] 
33. Klingelfus, T.; Disner, G.R.; Voigt, C.L.; Alle, L.F.; Cestari, M.M.; Leme, D.M. Nanomaterials induce DNA-protein crosslink and DNA oxidation: A mechanistic study with RTG-2 fish cell line and Comet assay modifications. Chemosphere 2019, 215, 703-709. [CrossRef] [PubMed]

34. Zhu, Z.-J.; Carboni, R.; Quercio, M.J., Jr.; Yan, B.; Miranda, O.R.; Anderton, D.L.; Arcaro, K.F.; Rotello, V.M.; Vachet, R.W. Surface properties dictate uptake, distribution, excretion, and toxicity of nanoparticles in fish. Small 2010, 6, 2261-2265. [CrossRef] [PubMed]

35. Cazenave, J.; Ale, A.; Bacchetta, C.; Rossi, A.S. Nanoparticles toxicity in fish models. Curr. Pharm. Des. 2019, 25, 3927-3942. [CrossRef] [PubMed]

36. Lajmanovich, R.C.; Peltzer, P.M.; Martinuzzi, C.S.; Attademo, A.M.; Colussi, C.L.; Bassó, A. Acute toxicity of colloidal silicon dioxide nanoparticles on amphibian larvae: Emerging environmental concern. Int. J. Environ. Res. 2018, 12, 269-278. [CrossRef]

37. Mouchet, F.; Landois, P.; Puech, P.; Pinelli, E.; Flahaut, E.; Gauthier, L. Carbon nanotube ecotoxicity in amphibians: Assessment of multiwalled carbon nanotubes and comparison with double-walled carbon nanotubes. Nanomedicine 2010, 5, 963-974. [CrossRef]

38. He, X.; Aker, W.G.; Leszczynski, J.; Hwang, H.-M. Using a holistic approach to assess the impact of engineered nanomaterials inducing toxicity in aquatic systems. J. Food Drug Anal. 2014, 22, 128-146. [CrossRef]

39. Santhiya, N.; Sanjeevi, S.B.; Gayathri, M.; Dhanalakshmi, M. Economic importance of marine molluscs. Res. Environ. Life Sci. 2013, 6, 129-132.

40. Ramasamy, S. Biology and ecology of edible marine bivalve molluscs. In Biology and Ecology of Edible Marine Bivalve Molluscs; Santhanam, R., Ed.; Apple Academic Press: New York, USA, 2018; pp. 15-23.

41. Burgos-Aceves, M.A.; Faggio, C. An approach to the study of the immunity functions of bivalve haemocytes: Physiology and molecular aspects. Fish Shellfish Immunol. 2017, 67, 513-517. [CrossRef]

42. Aguirre-Rubí, J.R.; Ortiz-Zarragoitia, M.; Izagirre, U.; Etxebarria, N.; Espinoza, F.; Marigómez, I. Prospective biomonitor and sentinel bivalve species for pollution monitoring and ecosystem health disturbance assessment in mangrove-lined Nicaraguan coasts. Sci. Total Environ. 2019, 649, 186-200. [CrossRef]

43. Rosa, M.; Ward, J.E.; Shumway, S.E. Selective capture and ingestion of particles by suspension-feeding bivalve molluscs: A review. J. Shellfish Res. 2018, 37, 727-746. [CrossRef]

44. Canesi, L.; Gallo, G.; Gavioli, M.; Pruzzo, C. Bacteria-hemocyte interactions and phagocytosis in marine bivalves. Microsc. Res. Tech. 2002, 57, 469-476. [CrossRef] [PubMed]

45. Kulikova, V.A.; Kolotukhina, N.K.; Omelyanenko, V.A. Pelagic larvae of the bivalves of Ussuriysky Bay, Sea of Japan. Russ. J. Mar. Biol. 2013, 39, 440-446. [CrossRef]

46. Belcheva, N.N.; Dovzhenko, N.V.; Istomina, A.A.; Zhukovskaya, A.F.; Kukla, S.P. The antioxidant system of the Gray's mussel Crenomytilus grayanus (Dunker, 1853) and the Japanese scallop Mizuhopecten yessoensis (Jay, 1857) (Mollusca: Bivalvia). Russ. J. Mar. Biol. 2016, 42, 489-494. [CrossRef]

47. Selin, N.I.; Vekhova, E.E. Effects of environmental factors on byssal thread formation in some members of the family Mytilidae from the Sea of Japan. Russ. J. Mar. Biol. 2004, 30, 306-313. [CrossRef]

48. Dinesen, G.E.; Morton, B. Review of the functional morphology, biology and perturbation impacts on the boreal, habitat-forming horse mussel Modiolus modiolus (Bivalvia: Mytilidae: Modiolinae). Mar. Biol. Res. 2014, 10, 845-870. [CrossRef]

49. Luk'yanova, O.N. Molecular biomarkers of energy metabolism in mussels under anthropogenic pollution of Peter the Great Bay, the Sea of Japan. Russ. J. Ecol. 2006, 37, 205-209. [CrossRef]

50. Podgurskaya, O.V.; Kavun, V.Y. Assessment of the adaptation capabilities of the bivalves Modiolus modiolus (Linnaeus, 1758) and Crenomytilus grayanus (Dunker, 1853) under increased levels of heavy metals in the environment. Russ. J. Mar. Biol. 2012, 38, 188-196. [CrossRef]

51. Galysheva, Y.A. Subtidal macrobenthos communities of Vostok Bay (Sea of Japan) under conditions of anthropogenic impact. Russ. J. Mar. Biol. 2004, 30, 363-370. [CrossRef]

52. Parrino, V.; Costa, G.; Cannavà, C.; Fazio, E.; Bonsignore, M.; Concetta, S.; Piccione, G.; Fazio, F. Flow cytometry and micro-Raman spectroscopy: Identification of hemocyte populations in the mussel Mytilus galloprovincialis (Bivalvia: Mytilidae) from Faro Lake and Tyrrhenian Sea (Sicily, Italy). Fish Shellfish Immunol. 2019, 87, 1-8. [CrossRef]

53. Barjhoux, I.; Rioult, D.; Geffard, A.; Palos Ladeiro, M. A new protocol for the simultaneous flow cytometric analysis of cytotoxicity and immunotoxicity on zebra mussel (Dreissena polymorpha) hemocytes. Fish Shellfish Immunol. 2020, 98, 224-235. [CrossRef] [PubMed] 
54. Moore, M.N.; Readman, J.A.; Readman, J.W.; Lowe, D.M.; Frickers, P.E.; Beesley, A. Lysosomal cytotoxicity of carbon nanoparticles in cells of the molluscan immune system: An in vitro study. Nanotoxicology 2009, 3, 40-45. [CrossRef]

55. Katsumiti, A.; Arostegui, I.; Oron, M.; Gilliland, D.; Valsami-Jones, E.; Cajaraville, M.P. Cytotoxicity of Au, $\mathrm{ZnO}$ and $\mathrm{SiO}_{2}$ NPs using in vitro assays with mussel hemocytes and gill cells: Relevance of size, shape and additives. Nanotoxicology 2016, 10, 185-193. [PubMed]

56. Katsumiti, A.; Gilliland, D.; Arostegui, I.; Cajaraville, M.P. Cytotoxicity and cellular mechanisms involved in the toxicity of CdS quantum dots in hemocytes and gill cells of the mussel Mytilus galloprovincialis. Aquat. Toxicol. 2014, 153, 39-52. [CrossRef]

57. Kuznetsov, V.L.; Elumeeva, K.V.; Ishchenko, A.V.; Beylina, N.Y.; Stepashkin, A.A.; Moseenkov, S.I.; Plyasova, L.M.; Molina, I.Y.; Romanenko, A.I.; Anikeeva, O.B.; et al. Multi-walled carbon nanotubes with ppm level of impurities. Phys. Status Solidi B 2010, 247, 2695-2699. [CrossRef]

58. Pikula, K.S.; Zakharenko, A.M.; Chaika, V.V.; Vedyagin, A.A.; Orlova, T.Y.; Mishakov, I.V.; Kuznetsov, V.L.; Park, S.; Renieri, E.A.; Kahru, A.; et al. Effects of carbon and silicon nanotubes and carbon nanofibers on marine microalgae Heterosigma akashiwo. Environ. Res. 2018, 166, 473-480. [CrossRef]

59. Han, S.C.; Park, S.E. Synthesis and characterization of silica nanotube by glycyldodecylamide as a template. Bull. Korean Chem. Soc. 2010, 31, 3519-3520. [CrossRef]

60. Mintcheva, N.; Gicheva, G.; Panayotova, M.; Wunderlich, W.; Kuchmizhak, A.A.; Kulinich, S.A. Preparation and photocatalytic properties of CdS and $\mathrm{ZnS}$ nanomaterials derived from metal xanthate. Materials 2019, 12, 3313. [CrossRef]

61. Kimling, J.; Maier, M.; Okenve, B.; Kotaidis, V.; Ballot, H.; Plech, A. Turkevich method for gold nanoparticle synthesis revisited. J. Phys. Chem. B 2006, 110, 15700-15707. [CrossRef]

62. Anisimova, A.A. Flow cytometric and light microscopic identification of hemocyte subpopulations in Modiolus kurilensis (Bernard, 1983) (Bivalvia: Mytilidae). Russ. J. Mar. Biol. 2012, 38, 406-415. [CrossRef]

63. Ostrander, G.K. Techniques in Aquatic Toxicology; CRC Press: Boca Raton, FL, USA, 2005; Volume 2.

64. Suzuki, T.; Fujikura, K.; Higashiyama, T.; Takata, K. DNA staining for fluorescence and laser confocal microscopy. J. Histochem. Cytochem. 1997, 45, 49-53. [CrossRef] [PubMed]

65. Crowley, L.C.; Scott, A.P.; Marfell, B.J.; Boughaba, J.A.; Chojnowski, G.; Waterhouse, N.J. Measuring cell death by propidium iodide uptake and flow cytometry. Cold Spring Harb. Protoc. 2016, 2016, pdb-prot087163. [CrossRef] [PubMed]

66. Sabnis, R.W.; Deligeorgiev, T.G.; Jachak, M.N.; Dalvi, T.S. DiOC 6 (3): A useful dye for staining the endoplasmic reticulum. Biotech. Histochem. 1997, 72, 253-258. [CrossRef] [PubMed]

67. Grégori, G.; Denis, M.; Lefèvre, D.; Beker, B. A flow cytometric approach to assess phytoplankton respiration. In Advanced Flow Cytometry: Applications in Biological Research; Springer Netherlands: Dordrecht, The Netherlands, 2003; pp. 99-106.

68. Anisimova, A.A.; Lukyanova, O.N.; Chaika, V.V.; Kalitnik, A.A.; Danilenko, S.A.; Kuznetsov, V.L.; Golokhvast, K.S. Short-Time Effect of Multi-Walled Carbon Nanotubes on Some Histological and Biochemical Parameters in Marine Bivalves Crenomytilus grayanus (Dunker, 1853) and Swiftopecten swifti (Bernardi, 1858). Nano Hybrids 2017, 13, 225-231. [CrossRef]

69. Anisimova, A.; Chaika, V.; Kuznetsov, V.; Golokhvast, K. Study of the influence of multiwalled carbon nanotubes $(12-14 \mathrm{~nm})$ on the main target tissues of the bivalve Modiolus modiolus. Nanotechnol. Russ. 2015, 10, 278-287. [CrossRef]

70. Smolka, W.; Panek, A.; Gubernat, M.; Szczypta-Fraczek, A.; Jelen, P.; Paluszkiewicz, C.; Markowski, J.; Blazewicz, M. Structure and Biological Properties of Surface-Engineered Carbon Nanofibers. J. Nanomater. 2019, 2019, 4146190. [CrossRef]

71. Rivera-Briso, A.L.; Aachmann, F.L.; Moreno-Manzano, V.; Serrano-Aroca, Á. Graphene oxide nanosheets versus carbon nanofibers: Enhancement of physical and biological properties of poly (3-hydroxybutyrate-co-3-hydroxyvalerate) films for biomedical applications. Int. J. Biol. Macromol. 2020, 143, 1000-1008. [CrossRef]

72. Barrick, A.; Manier, N.; Lonchambon, P.; Flahaut, E.; Jradd, N.; Mouneyrac, C.; Chatel, A. Investigating a transcriptomic approach on marine mussel hemocytes exposed to carbon nanofibers: An in vitro/in vivo comparison. Aquat. Toxicol. 2019, 207, 19-28. [CrossRef] 
73. Miller, M.; Bankier, C.; Al-Shaeri, M.; Hartl, M.G. Neutral red cytotoxicity assays for assessing in vivo carbon nanotube ecotoxicity in mussels-Comparing microscope and microplate methods. Mar. Pollut. Bull. 2015, 101, 903-907. [CrossRef]

74. Pikula, K.; Chaika, V.; Zakharenko, A.; Markina, Z.; Vedyagin, A.; Kuznetsov, V.; Gusev, A.; Park, S.; Golokhvast, K. Comparison of the level and mechanisms of toxicity of carbon nanotubes, carbon nanofibers, and silicon nanotubes in bioassay with four marine microalgae. Nanomaterials 2020, 10, 485. [CrossRef]

75. Canesi, L.; Ciacci, C.; Betti, M.; Fabbri, R.; Canonico, B.; Fantinati, A.; Marcornini, A.; Pojana, G. Immunotoxicity of carbon black nanoparticles to blue mussel hemocytes. Environ. Int. 2008, 34, 1114-1119. [CrossRef] [PubMed]

76. Fubini, B.; Ghiazza, M.; Fenoglio, I. Physico-chemical features of engineered nanoparticles relevant to their toxicity. Nanotoxicology 2010, 4, 347-363. [CrossRef] [PubMed]

77. Perl, A.; Gergely, P., Jr.; Nagy, G.; Koncz, A.; Banki, K. Mitochondrial hyperpolarization: A checkpoint of T-cell life, death and autoimmunity. Trends Immunol. 2004, 25, 360-367. [CrossRef]

78. Berghe, T.V.; Vanlangenakker, N.; Parthoens, E.; Deckers, W.; Devos, M.; Festjens, N.; Guerin, C.; Brunk, U.; Declercq, W.; Vandenabeele, P. Necroptosis, necrosis and secondary necrosis converge on similar cellular disintegration features. Cell Death Differ. 2010, 17, 922-930. [CrossRef] [PubMed]

79. Hoshino, A.; Hanada, S.; Yamamoto, K. Toxicity of nanocrystal quantum dots: The relevance of surface modifications. Arch. Toxicol. 2011, 85, 707. [CrossRef]

80. Silva, B.F.; Andreani, T.; Gavina, A.; Vieira, M.N.; Pereira, C.M.; Rocha-Santos, T.; Pereira, R. Toxicological impact of cadmium-based quantum dots towards aquatic biota: Effect of natural sunlight exposure. Aquat. Toxicol. 2016, 176, 197-207. [CrossRef]

81. Pikula, K.; Mintcheva, N.; Kulinich, S.A.; Zakharenko, A.; Markina, Z.; Chaika, V.; Orlova, T.; Mezhuev, Y.; Kokkinakis, E.; Tsatsakis, A.; et al. Aquatic toxicity and mode of action of CdS and ZnS nanoparticles in four microalgae species. Environ. Res. 2020, 186, 109513. [CrossRef]

82. Lee, G.-J.; Wu, J.J. Recent developments in $\mathrm{ZnS}$ photocatalysts from synthesis to photocatalytic applications -A review. Powder Technol. 2017, 318, 8-22. [CrossRef]

83. Benjamin, M.M. Water Chemistry; Waveland Press: Long Grove, IL, USA, 2014; pp. 215-291.

84. Wang, B.; Zhang, Y.; Mao, Z.; Yu, D.; Gao, C. Toxicity of ZnO nanoparticles to macrophages due to cell uptake and intracellular release of zinc ions. J. Nanosci. Nanotechnol. 2014, 14, 5688-5696. [CrossRef]

85. Pikula, K.S.; Zakharenko, A.M.; Aruoja, V.; Golokhvast, K.S.; Tsatsakis, A.M. Oxidative stress and its biomarkers in microalgal ecotoxicology. Curr. Opin. Toxl. 2019, 13, 8-15. [CrossRef]

86. Donaghy, L.; Hong, H.-K.; Jauzein, C.; Choi, K.-S. The known and unknown sources of reactive oxygen and nitrogen species in haemocytes of marine bivalve molluscs. Fish Shellfish Immunol. 2015, 42, 91-97. [CrossRef] [PubMed]

87. Bishop, G.M.; Dringen, R.; Robinson, S.R. Zinc stimulates the production of toxic reactive oxygen species (ROS) and inhibits glutathione reductase in astrocytes. Free Radic. Biol. Med. 2007, 42, 1222-1230. [CrossRef] [PubMed]

88. Haider, A.J.; AL-Anbari, R.H.; Kadhim, G.R.; Salame, C.T. Exploring potential environmental applications of $\mathrm{TiO}_{2}$ nanoparticles. Energy Procedia 2017, 119, 332-345. [CrossRef]

89. Waghmode, M.S.; Gunjal, A.B.; Mulla, J.A.; Patil, N.N.; Nawani, N.N. Studies on the titanium dioxide nanoparticles: Biosynthesis, applications and remediation. SN Appl. Sci. 2019, 1, 310. [CrossRef]

90. Clément, L.; Hurel, C.; Marmier, N. Toxicity of $\mathrm{TiO}_{2}$ nanoparticles to cladocerans, algae, rotifers and plants-Effects of size and crystalline structure. Chemosphere 2013, 90, 1083-1090. [CrossRef] [PubMed]

91. Haynes, V.N.; Ward, J.E.; Russell, B.J.; Agrios, A.G. Photocatalytic effects of titanium dioxide nanoparticles on aquatic organisms-Current knowledge and suggestions for future research. Aquat. Toxicol. 2017, 185, 138-148. [CrossRef]

92. Rocher, B.; Le Goff, J.; Peluhet, L.; Briand, M.; Manduzio, H.; Gallois, J.; Devier, M.H.; Geffard, O.; Gricourt, L.; Augagneur, S.; et al. Genotoxicant accumulation and cellular defence activation in bivalves chronically exposed to waterborne contaminants from the Seine River. Aquat. Toxicol. 2006, 79, 65-77. [CrossRef]

93. Alex, S.; Tiwari, A. Functionalized Gold Nanoparticles: Synthesis, Properties and Applications-A Review. J. Nanosci. Nanotechnol. 2015, 15, 1869-1894. [CrossRef] 
94. Volland, M.; Hampel, M.; Martos-Sitcha, J.A.; Trombini, C.; Martínez-Rodríguez, G.; Blasco, J. Citrate gold nanoparticle exposure in the marine bivalve Ruditapes philippinarum: Uptake, elimination and oxidative stress response. Environ. Sci. Pollut. Res. 2015, 22, 17414-17424. [CrossRef]

95. Tedesco, S.; Doyle, H.; Redmond, G.; Sheehan, D. Gold nanoparticles and oxidative stress in Mytilus edulis. Mar. Environ. Res. 2008, 66, 131-133. [CrossRef]

(C) 2020 by the authors. Licensee MDPI, Basel, Switzerland. This article is an open access article distributed under the terms and conditions of the Creative Commons Attribution (CC BY) license (http://creativecommons.org/licenses/by/4.0/). 